\title{
FIGHTING NUISANCE ON THE NORTHERN FRINGE
}

\section{Controlling mosquitoes in Britain between the World Wars}

\section{Peter Coates}

\begin{abstract}
"Mosquito pest conference-in England!" This incredulous headline appeared in a London-based magazine, West Africa, which covered news items about Britain's West African colonies. ${ }^{1}$ Whether in the 1920 s or at other times in the twentieth century, the British tendency has been to think that mosquito problems were "far away." The 34 species of mosquitoes native to Britain, admittedly, is a modest, even trifling number compared to the global total of circa 3,500 species. And most of Britain's mosquitoes do not even belong to the disease-transmitting family. Britain's mosquitoes are categorized as nuisance mosquitoes-after all, West Africa referred to the mosquito as (mere) pest. Just five British mosquitoes are Anopheline and only one, Anopheles atroparvus, Europe's major malaria carrier, breeds in big enough numbers and sufficiently close to humans to serve as an efficient vector of one of malaria's main parasites, Plasmodium vivax (West Africa 1927, BMCI, AMWL; Manchester Guardian 1929: 8; Snow 1998: 9; Marshall 1938: 2). ${ }^{2}$
\end{abstract}

But a comparatively small number of lethal varieties does not mean that the mosquito chapter of British domestic history is unimportant. A century and a half ago, the connection between Britain and mosquitoes was stronger. Anopheles atroparvus was apparently the species that transmitted a native strain of malaria known as ague. Endemic for centuries to the coastal marshlands of Essex and Kent, and watery lowlands including the fenlands of East Anglia and the Somerset Levels in southwest England, ague — aka marsh fever-killed or debilitated thousands of young, old, undernourished, sick and poorer residents of wetland regions (Dobson 1998: 312, 321). By 1900, ague had pretty much died out, not because the parasite's mosquito vector had been eliminated, but thanks to extensive drainage, advances in public health care and improved sanitation. Increased separation of human dwellings from livestock and a growing cattle population also transformed mosquito biting habits by providing alternative sources of blood meals (Peacock 
1859: 453, 478; James 1929: 71-87; MacArthur 1951: 76-79). ${ }^{3}$ Combined with decreasing virulence of the malaria parasite, growing resistance in the human patient and greater availability of quinine, lowland England saw this scourge disappear. ${ }^{4}$ Once ague was gone, the mosquito, itself, effectively disappeared from domestic British history - although British imperial history is another matter.

This chapter explores questions of control, and the desirability and feasibility of elimination from the unlikely perspective of Britain's interwar mosquito experience. ${ }^{5}$ The case study considered here is the British Mosquito Control Institute, or BMCI, established in 1925. This non-medical enterprise started out five years earlier as the Hayling Mosquito Control in the English Channel's resort of Hayling Island near Portsmouth, to combat a particular nuisance mosquito that was making local residents' and vacationers' lives miserable. The Institute's locally successful "anti-mosquito crusade" from 1921 to 1924 (Daily Mail 1925: 15), subsequently expanded under a new name in purpose-built premises (1925-1939), is examined within a wider geographical framework that includes campaigns to eliminate deadly varieties of mosquito, from Italy's Pontine Marshes to the Panama Canal and various parts of Britain's empire (Birmingham Post 1927; Morning Post 1925a). "From Nairobi to Hayling Island is a far cry," ruminated a local journalist, "but it sounds in our ears" (Portsmouth Gazette 1930).

The deadly-disease-carrying mosquitoes of Nairobi can be regarded, from a strictly biological standpoint, as a human population reduction agent; or, as entomologist Daniel Strickman of the US Department of Agriculture observed bluntly a decade ago, "The ecological effect of eliminating harmful mosquitoes is that you have more people" (Fang, 2010: 432). But even if there were no human lives to be saved in combatting non-lethal mosquitoes in Hayling Island, one should not underestimate the efforts expended against what Sir Ronald Ross referred to as, at first sight, a "wholly insignificant creature" (Ross 1926: 481). Ross, who began his malaria research in India 30 years earlier, and was now director-in-chief of London's Ross Institute and Hospital for Tropical Diseases, made this remark at BMCI's opening day on 31 August 1925. To gain a deeper understanding of the non-lethal mosquitoes that inflicted such "injuries" as depressed real estate value and lost tourist revenue, I situate the BMCI's exploits within parallel efforts across the North Atlantic to control nuisance mosquitoes in coastal New Jersey. I then compare control strategies adopted at Hayling Island with larger-scale, more heavily chemicalized interventions beyond Britain after the first deployment of DDT in 1942 and the subsequent worldwide war against malaria. Such comparisons allow us to engage with themes of imperialism, macro- and micro-strategies of control as well as species sanitation. We will find a consensus among applied entomologists in Britain regarding the desirability of controlling nuisance mosquitoes, but a recognition that doing so was not always feasible.

It should also be pointed out that mosquitoes need not carry deadly diseases to be lethal to humans or non-humans. Technically non-lethal varieties claim the occasional human death from, say, septicaemia when a bite becomes inflamed and infected, resulting in blood poisoning. A. Moore Hogarth, the founder and chairman of the London College of Pestology, recorded 21 deaths 
over a seven-year period in Britain (1921-1928) that were "definitely traced or at least reasonably attributed to mosquito bites" (Hogarth 1928: 40-42). The focus here, though, is on the "discomfort" and "general annoyance" mosquitoes of the inter-war period inflicted (Marshall [undated A], MP, LSHTM ${ }^{6}$; Simpson ${ }^{7}$ in Hogarth 1928: 15).

\section{In search of comfort}

The British press reported with gusto the declaration of war on the pesky mosquito on Hayling Island in 1920 and did not flag in its coverage of the subsequent waging of warfare against the insect "enemy" (Daily Express 1920; Turnbull 1925: 228; Morning Post 1925b; Evening Standard 1925). This coverage cannot be fully appreciated without reference to malaria contracted in Britain during the latter stages of World War One by soldiers and civilians who had never set foot abroad. The sites and distribution of locally contracted cases from August 1917 onward closely matched the incidence of indigenous malaria in 1860, with the highest numbers along the south and southeast coasts (Ministry of Health (MoH) 1949, Appendix IV, 33). ${ }^{8}$ In north Kent, for example, at the military camps and hospital near Sheerness, Isle of Sheppey, and at Grain Fort, Isle of Grain, Anopheles mosquitoes were "generally abundant" in the "marshland and stagnant pools, intersected with dykes [that] surround the station" as well as indoors (Parsons 1919: 95-112; Newman 1919: 11). Ministry of Health officials reckoned demobilized troops brought in the parasite from the Salonika campaign, as well as from Mesopotamia, Egypt and German East Africa (Macdonald 1919: 179-180, 184, 193; Ross 1919: 324; James 1920: 83-93).

Medical authorities worried that infected soldiers or "carriers" bitten by local Anopheline mosquitoes would spread malaria across Britain during demobilization, at a time when $A$. maculipennis was "ubiquitous and extraordinarily numerous" (James 1920: 81-83, 85) (Figure 7.1). An official source logged 178 documented cases of malaria of "indigenous" origin in southeast England in 1917 with none classified as severe, being all "Benign tertian" and with no deaths (Grove 1919: 44-50). This hardly constituted a major public health problem. Yet the report's author was troubled by Anopheles' presence "sometimes in notable abundance, practically in any part of England where the conditions are favourable to their breeding" (Newsholme 1918: A2).

Inspired by successful control of yellow fever and malaria in the Canal Zone of Panama with drainage and larvicide-and similar initiatives in Egypt and Sudan-the Royal Army Medical Corps' First London Sanitary Company was assigned to control "dangerous areas" such as north Kent. The detachment not only applied chemical larvicides to self-contained pools and sheep-dipping wells, it also fumigated farm steadings and cleaned cobwebby attics and limewashed stables where A. maculipennis hibernated. Mainly, though, its job consisted of routine maintenance work neglected by civil authorities during wartime such as clearing the "quagmire of vegetation" from ditches, dykes and ponds, 


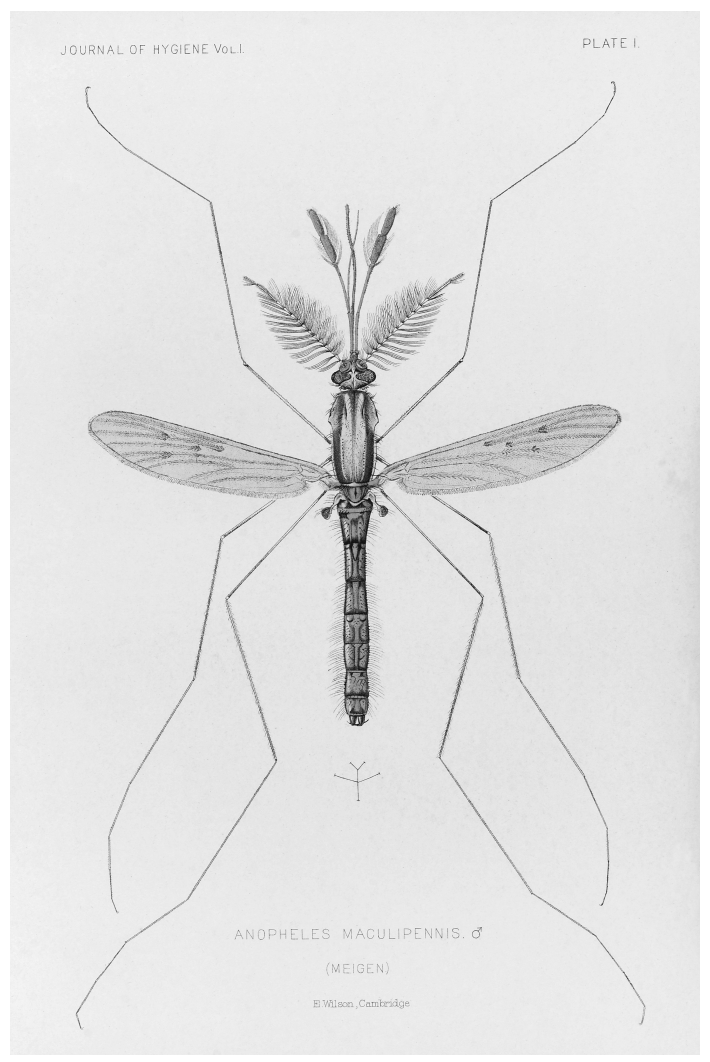

FIGURE 7.1 Male mosquito, Anopheles maculipennis (atroparvus), 1901. Credit: Wellcome Collection. Attribution 4.0 International (CC BY 4.0).

"brushing the shores" and filling in derelict canals that multiplied mosquito habitat. Collectively, these tasks were described as anti-malaria measures, not anti-mosquito measures (Macdonald 1919: 175, 249, 245-246, 248, 251, 255; Buchanan and Newsholme 1919: iv; Macfarlane 2012). The objective was "limitation" and "reduction," not eradication, a modesty of ambition that characterized anti-malaria measures as "petty." The informing "principles" were to limit the extent of "open water" and otherwise diminish water bodies' suitability as breeding grounds (Macdonald 1919: 248-249, 254).

\section{The gravity of the menace ${ }^{9}$}

With locally contracted cases of nonindigenous malaria drying up once all troops were back, and the First London Sanitary Company clipping the wings of Anopheles in north Kent, a new war on a different kind of mosquito began 
along the marshy coast of Hampshire. This 1920 campaign is rumoured to have started when the BMCI's founder, John F. Marshall, a trained mechanical engineer, barrister and, later, self-taught entomologist, found that guests at his Hayling Island villa were complaining of being bitten by mosquitoes while playing tennis and afterward "eating their cucumber sandwiches on the lawn" (Service 2003, BMCI, AMWL). ${ }^{10}$ Hogarth recalled that Hayling Island had become "almost uninhabitable" and was "rapidly ceasing to exist as a pleasureresort" (Hogarth 1928: 48). Marshall reported that residents usually "vacate their homes in July and August, and leave the island as far as possible to the mosquitoes" (Marshall 1930, MP, LSHTM). ${ }^{11}$ He related how "a visitor arriving at a house adjoining the Salterns [on the edge of the saltmarshes] for a projected stay of some weeks [September 1922] was compelled to depart on the next day" (Marshall 1924, Marshall, LSHTM). When Sir Ronald Ross first visited the island in August 1922, he underestimated the gravity of the problem. Until, that is, Marshall

took me to a sheltered spot in his garden where there were innumerable mosquitoes. It was then that I suddenly found two or three of them engaging in extracting blood from the back of my neck. I have seldom had such an experience, even in the West Indies.

(Daily News 1925)

Garden parties were not the only outdoor activities mosquitoes ruined. And Hayling Island was not the only place afflicted. Various sources testify to the severity of the mosquito "scare" along England's south coast during the 1920s, and how, to quote Country Life magazine, a bite could destroy the "whole idyll of a summer evening" (Manchester Guardian 1925; Times [London] 1926; Country Life 1926: 4). According to the Ministry of Health's advisor on tropical diseases, Colonel S.P. James, who was also a member of BMCI's governing council, "the abundance of these insects in nearly every rural district ... is greater than in many exceedingly malarious places in the tropics" (James 1929: 75). ${ }^{12}$

High society's mosquito "problem" stemmed from greater numbers combined with closer human-insect contact. Expansion of breeding grounds also encouraged larger populations. "The Salterns" area of southeastern Hayling Island had been reclaimed from the nearby estuary by building earthen sea walls, but such coastal defences had slid into disrepair over the decades. This neglect restored stagnant, brackish waters that made excellent breeding grounds for Aedes (Ochlerotatus) detritus, one of two British saltwater varieties, which, of the 17 local mosquito species, was soon identified as the main culprit (Marshall 1924, MP, LSHTM; MoH 1949: 18-19; Nature 1949: 16). Breeding sites for nuisance varieties such as $A$. detritus were not only restored; they also resulted from unintended environmental transformations. Humans had enlarged mosquito empires across the tropical world through jungle clearance and various landscape disrupting "earth-works" (James 1920: 16-17; Sutter 2007: 743-745). 
And wartime and post-war Britain was no exception to the human enlargement of mosquito breeding sites, as Willoughby's chapter attests. Water accumulated in pockets left by wartime bombings and latrines dug at military camps. Newly fashioned recreational landscapes were also mosquito-friendly, with golf's rising popularity leading to a multiplication of courses that incorporated water features, or outdoor camping spreading empty sardine tins and jam jars (Hogarth 1928: 5758; $\mathrm{MoH}$ 1949: 18: $\mathrm{MoH}$ 1962: 5, 21). Greater numbers of people travelling and spending time out of doors exposed more human flesh, and so promoted more human-mosquito encounters (Hogarth 1928: 48).

Marshall's Institute was not only the first attempt in the United Kingdom to combat nuisance mosquitoes. It also furnished the UK's only opportunity "for studying the various details of a mosquito control organization in actual and continuous operation," not least by showcasing the particular challenges of undertaking these studies in a residential area (Marshall 1924: 10). Existing publications (in English) about mosquitoes and their control were focused largely on disease-carrying mosquitoes in "foreign parts," and so practically irrelevant to controlling Britain's non-lethal varieties (Marshall 1928: 4). (Figure 7.2) Those

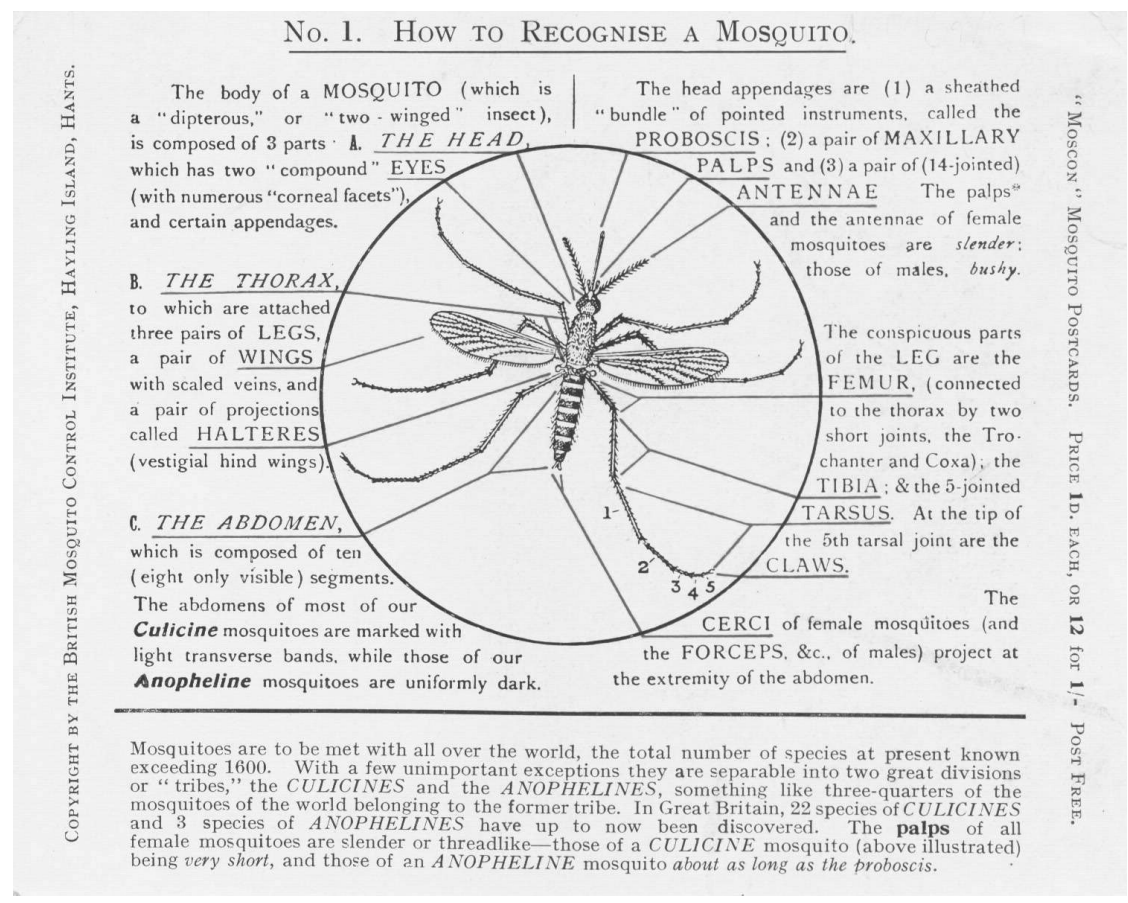

FIGURE 7.2 "How to recognise a mosquito" in John F. Marshall, A Mosquito Summary (Hayling Island: British Mosquito Control Institute) [undated], p. 1. Credit: In the possession of Jolyon Medlock, Public Health England. Reproduced courtesy of Jolyon Medlock. 
who oversaw the Institute's activities were nonetheless steeped in the context of the tropics: "men learned in the ways of mosquitoes in India, the Gold Coast, or at Khartoum, where it is not merely a nuisance" (The Children's Newspaper 1928, Marshall, LSHTM). When the BMCI began to identify and study the habits of Britain's non-Anopheline mosquitoes, it would borrow heavily from the methods of the tropics.

One example of the transfer of knowledge from tropical to temperate was the formation of a small local workforce known as a Mosquito Brigade, a practice Ross pioneered in the Indian Medical Service. The task of these brigades was to wipe out or treat with petroleum all sources of standing water, not only all marshes, ponds and ditches, but also puddles and water accumulated in tree boles, sites that would not have been considered as breeding environments when the miasma theory held sway (Ross 1902; Christophers and Bentley 1908: 21-22). Ross-style brigades came to play a particularly vital role on Hayling Island because local public authorities felt non-lethal mosquito control was not their responsibility. In many countries, as Marshall pointed out, the owner of the land on which mosquitoes breed is required by law to bear part of the costs of control, besides providing controllers access to the land. Hogarth pointed out that in New South Wales, Australia, powers to enforce mosquito destruction had been vested in local governments since 1906 (Hogarth 1928: 111-113; O’Gorman 2017: 496). However, in Britain, despite the Public Health Act of 1876, which included "any pool, ditch, gutter, watercourse, sink, cistern, cesspool or drain so foul or in such as state or so situated as to be nuisance or injurious or dangerous to health," local municipalities had been reluctant to act on mosquito control (Westminster Gazette 1927; Yorkshire Post 1927). The official line the town council adopted in a southcoast resort in nearby Dorset was that "there are no mosquitoes in Weymouth." Disputing this, one of Hogarth's correspondents insisted that the council was actually "afraid of the existence of mosquitoes getting known" for fear of putting off visitors, and so, "takes no steps to destroy them" (Hogarth 1928: 50). Marshall also suspected that many seaside resorts adhered to a do-nothing policy because they figured that "first-time" blissfully mosquito-unaware visitors would come in sufficient quantities to compensate for those who did not return because of the nasty mosquito surprises awaiting them (Marshall 1928: 37).

Another obstacle faced proponents of control. Not only was permission required to “drain away [a private landowner's] mosquito-infested waters" but funding for control work needed to be secured (Marshall 1928: 37). BMCI (an incorporated organization) and its predecessor, the Hayling Mosquito Control, were unofficial initiatives, funded entirely from private sources (largely Marshall's personal wealth), since the Ministry of Health had no mandate to spend public funds on non-lethal mosquitoes (Marshall 1928: 10). Given the government's lack of support, "education of local public opinion in support of the work" was particularly essential (Marshall 1927: 9). One local headmaster, for example, organized an annual "Mosquito Control Class" where he enlisted schoolchildren to collect samples (Marshall 1928: 10; Lancet 1925). 


\section{A pleasure-killing pest across the Atlantic}

The existence of a type of juvenile Mosquito Brigade at Hayling Island demonstrates how a local temperate-zone mosquito campaign was shaped by more lethal threats faced by its distant tropical counterparts. Beyond Britain's tropical colonies, the Institute's awareness and frame of reference also extended to American efforts to combat disease-bearing mosquitoes, especially in Cuba, Panama and the Philippines where yellow fever and malaria had raged (Daily Mirror 1925; Observer 1925: 5). Yet mosquito control within US borders provides a closer parallel with BMCI's efforts. Only rarely did Marshall, or the press and medical journals, acknowledge that the main precedent for controlling "general annoyance" mosquitoes was from the United States' northeast coast (Marshall, undated A: 3, Marshall, LSHTM; Marshall 1925b: 6, 17; British Medical Journal [BMJ] 1930: 328).

Organized efforts to deal with comparable saltwater mosquitoes, such as Aedes sollicitans, the white-banded salt marsh mosquito, began in coastal marshlands of states such as New Jersey in the early 1900s. "Magnificent dwellings," lamented a realtor in the 1890 s,

find no purchasers because ... as soon as dark sets in, piazzas must be abandoned to escape the annoyance of these little nuisances. In almost any car in any morning train to the city during the summer, somebody may be heard talking of mosquitoes.

(Smith 1904: 462, in Patterson 2009: 12)

Fifteen years later, Hayling Island residents and visitors expressed identical sentiments regarding what Americans dubbed the "pleasure killing pest" (Chicago Daily Tribune 1914). Indeed, Marshall's organization was a British equivalent of the village improvement societies and town protective associations that emerged in New Jersey from 1901, eventually broadening into state-level organizations such as the New Jersey Mosquito Control Association.

Like their British counterparts, Americans who fought Aedes sollicitans thought that eliminating this nuisance would deliver economic benefits, including more tourists and higher property values. Tensions within US mosquito-control circles were often framed as comfort versus disease: those concerned with public health wanting to curb lethal mosquitoes complained that politicians were more responsive to businesspeople moaning about lost profits (Patterson 2009: 88-89). As in England, awareness of a mosquito problem did not guarantee action. Weymouth town council's disinclination to acknowledge a local mosquito problem is a pattern of denial and inaction also observable in areas of the USA where mosquitoes were malarial. In northern California, irrigation infrastructure boosted land values but created excellent breeding conditions for anophelines, particularly where rice was cultivated and there were concomitant water seepages and leaks. Until 1915, many American 
realtors opposed public funding of mosquito control for fear that such efforts would only draw attention to the problem and deter prospective buyers (Patterson 2009: 83, 107, 122).

\section{A "practically intolerable"13 nuisance}

In 1924, prompted by the growing number of mosquito-bite-related illnesses, and even deaths, together with accumulating complaints about interference with outdoor pursuits, the council of Hogarth's College of Pestology offered a prize for the best essay on Britain's "Mosquito Menace." The competition attracted almost 500 entrants from across the world. The winner, P.G. Shute, an assistant to Colonel James and a veteran of anti-mosquito campaigns in the tropical British Empire, received his gold medal from Ross in the presence of various luminaries at a luncheon in London. Shute's central recommendation for combating Aedes detritus was to shrink its breeding grounds through drainage and infilling. ${ }^{14}$ Two other points emerged at the lunch that day. Firstly, the need to instil in public authorities, and a rather ignorant and apathetic public, an awareness of "the real urgency of the mosquito evil in this country" (Hogarth 1928: 18). The second imperative was to equip those whose enlistment would be crucial to the success of a coordinated campaign-Boy Scouts, Girl Guides and "village naturalist circles"-with the means "readily to distinguish and identify at least the more common and mischievous species of British mosquitoes" (Hogarth 1928: 18; Liverpool Evening Express 1928).

Despite this sense of urgency and their liberally employed rhetoric of warfare (Marshall 1925a: 475), Marshall and his associates did not exaggerate the threat that British mosquitoes posed. They scrupulously distinguished between species such as $A$. detritus and the Anopheline "tribe." They were also clear that nothing less than the disintegration of Britain's modern sanitary system would be required to re-establish malaria as a "native disease" (Hogarth 1928: 37). Nonetheless, for the likes of Hogarth, Marshall and Ross, "seaside" mosquitoes' non-lethality was no reason to accept they were an unavoidable part of life-as was the weather or taxes, about which you could complain ad nauseam, but just had to live with.

Marshall saw no possibility of coexistence at Hayling Island. Either he and his fellow residents had to go, or their little tormentors had to go (Olver 2014). It was a stand-off. Sir Richard Gregory, editor of Nature, who presided over the Institute's opening ceremony in 1925, also took the crusading "us or them" position:

Man to-day is "up against" the mosquito, and has to fight in order to live at all. In many places, it is a question of mosquito or man, and if the insect is permitted to breed without any control ... man must finally leave the place. 
One reporter offered the following headline of Gregory's talk: "Man against the insect: scientist says we must conquer or die" (Daily Express 1920; Western Mail 1925). Ross's opening address adopted a similar tone. Emphasizing the direct value to the world's tropical regions of the research conducted at this unlikely place, he cast mosquitoes of all kinds (indeed all pestiferous insects that preyed on us, our crops or livestock) as an insufferable affront to human authority:

Nothing in human history is more remarkable than the contrast between the comparatively rapid and easy victory of man over the great beasts and reptiles and his total helplessness throughout the ages in the face of attack by the tiniest of living things. The empire of the disease-bearing insects has, indeed, been very widely extended in many regions at the same time that ancient and modern weapons were swiftly exterminating the dangerous brutes.

("Mosquito control," Daily Telegraph, 2 September 1925: 8)

Ross gave his speech al fresco, before an audience of some 350, in the very garden where he was famously tormented in 1922 (and where Marshall's guests were unable to enjoy their refreshments). His former molesters' absence testified to the Hayling campaign's unambiguous success (Times 1925). By the summer of 1923, unsolicited testimonies from locals had already pointed to the remarkable elimination of mosquitoes. A happy repeat visitor reported to Marshall in August 1926 that during her current two-month stay, "I have not seen a mosquito with the exception of those in your [Institute's] cages" (Marshall 1924: 12; BMCI, 8th report 1930). The BMCI had apparently worked out not only which kind of mosquito was biting townsfolk and vacationers, but it had unleashed a multi-pronged assault on the larvae and breeding grounds of Aedes detritus.

\section{"No stagnating sea water, no mosquito nuisance"15}

The work at Hayling Island (covering under seven square miles) was targeted rather than indiscriminate, based on the conviction that control strategies should be micro-strategies, carefully tailored to the habits and micro-habitats of individual mosquito species rather than blanket spraying, as would occur in Sardinia after 1945 (Hall 2010). A researcher summed up the nuanced approach adopted on Hayling Island: "it is idle to blame the domestic water butt if the insects are coming from a pond in a neighbouring wood" (BMJ 1930 : 328). Marshall's team quickly learnt they were dealing with enormous diversity in species, hatching habits and breeding places (BMCI 17 May 1928, MP, LSHTM). Initial collecting activities in the autumn of 1920 disclosed that the "local nuisance" was almost exclusively caused by Aedes (Ochlerotatus) detritus, a species particularly active in daytime that was also exceptional among British mosquitoes for other reasons. It was not until the following summer, after experiments in a makeshift 
laboratory revealed that $A$. detritus would breed in stagnant water comparable in salinity to seawater, that Marshall and his staff figured it out. A. detritus was a "long-distance" species with an unusual flight range of up to five kilometres whose breeding grounds were situated two kilometres westward and eastward of its biting grounds in the central residential district (Marshall 1928: 9).

They also discovered that, exceptionally among British mosquitoes, A. detritus eggs and larvae can survive the winter. Eggs laid in dry marshland vegetation remained in suspended animation until submerged by tidal action or otherwise wetted. If the weather was mild, the production of adults could continue from April to November-a remarkably long hatching-out period for British mosquitoes (BMJ 1930: 328-329). The campaign's key finding? Successful control at the local level depends on establishing the precise identity of the problem-causing mosquito and thorough study of its attributes (Marshall 1927, BMCI, AMWL; Marshall, Nature 1942: 2). As Marshall explained:

Each species displays great discrimination as regards the special situations which it selects for its breeding, and its choice depends upon a number of factors which it no doubt understands better than we do. Certain species appear to possess a sufficient knowledge of engineering to enable them to lay their eggs in depressions ... which, although dried up at the time when eggs are deposited, are destined to collect water in the wetter months.

(Marshall, undated B: 3, Marshall, AMWL)

This approach belongs, of course, to an era before DDT was available as a superweapon in the mosquito controller's arsenal. Marshall's views on DDT are not recorded and we can only speculate over whether he would have embraced it wholeheartedly should it have been available in the 1920s. Gordon Patterson divides mosquito control in the USA into two eras before general uses of DDT were banned in 1972: the pre-DDT period of mechanical control (c. 1900 to 1942) and the period of chemical control (1942-1972) (Patterson 2016: 2). Adapting this periodization to the UK, the mechanical era is the same (c. 1900-1942) but the chemical era lasts longer, until 1986. Nuisance mosquito control before DDT was pursued in Britain through a blend of short- and longterm measures. The former consisted of larvae suffocation by spreading paraffin and crude oil or other chemicals on the water surface ${ }^{16}$ as well as biocontrol (in other words, leaving larvae-gobbling fish to do the job in certain water bodies). Long-term measures comprised "abolition" of existing and potential macro- and micro-level breeding grounds whether "natural" or "man-made" (MoH 1949: 20-26). The main methods adopted at Hayling Island, after A. detritus breeding grounds were pinpointed, were through drainage and infilling of marshlands ("a permanent cure" (Turnbull 1925: 228)).

Targeting of breeding grounds rather than mosquitoes themselves - a method also adopted, among others, on the Pontine marshes after 1922 but mainly during the $1930 \mathrm{~s}$ - was in stark contrast to the favoured strategy of some local 
authorities in England at the time: spraying stagnant waters within or close to residential areas. This was not just a waste of money, said the critics. Spraying's ineffectuality undermined public confidence in anti-mosquito activities more generally (Manchester Guardian 1929: 8; Country Life 1925: 430; Caprotti 2006: 145-155; The Field 1924: 502-503).

If a heavy-handed, heavily chemical, top-down approach that ignores species' particularities and specificities on the ground can be characterized as hard, and its more measured opposite as soft, then the Hayling Island approach was "an intimate strategy of detection and destruction of breeding sites" (to borrow a phrase from a study of divergent control strategies in two cities in Arizona, Tucson and Phoenix (Shaw et al. 2010: 375)). Biocontrol methods are not necessarily "soft" if they involve the introduction of a non-native species such as the mosquitofish, Gambusia. However, just as Hogarth had noted that industrial pollutants were killing off larvae-gobbling fish, helping explain nuisance mosquitoes' proliferation in southern England in the early 1920s, Marshall warned, in proto-ecological reasoning, against indiscriminate application of chemical larvicides and paraffin that might inflict collateral damage, wiping out the mosquito's "benevolent" "natural enemies" such as fish. Marshall and colleagues instructed their "mosquito brigades" that established water bodies such as cattle ponds and ornamental lakes contained natural allies in the form of fish and other amphibians that feast on eggs and larvae (Hogarth 1928: 57). ${ }^{17}$

In his writings, Marshall never referred to Surgeon Major William C. Gorgas, who led US sanitation campaigns in Cuba and Panama in the early 1900s. But Gorgas's appreciation of the heterogeneity of a potential breeding site, characterized as "on-the-ground, labor-intensive, and environmentally complex" (Shaw et al. 2010: 376), was something that also informed Marshall's every move. Gorgas famously remarked (allegedly, c. 1900) that to combat mosquitoes, one needed to think like a mosquito (Soper 1965: 860; Macdonald 1965: 871; Stepan 2011: 92). Marshall would have echoed these sentiments.

\section{If only we could, should we?}

Despite mission accomplished on Hayling Island-subject to regular inspection, maintenance of drainage works and treatment of stagnant water-Marshall accepted that "permanent eradication of mosquitoes from even a limited area is ... a matter of impossibility" (Marshall 1928: 27). This reflected respect for the indomitability of an opponent that has been around in the same form and life cycle for at least 80-105 million years and an appreciation of the limits of the science and technology, at least in the pre-DDT era. In today's discourse of ecosystem services and benefits, the presence of nuisance and disease-carrying, if sublethal, mosquito varieties within a wetland represent a potential disservice (Dwyer et al. 2016: 555, 557, 559-560; Knight et al. 2017: 431-440).

Marshall's views on whether the mosquito- $A$. detritus specifically, or more generally-possessed any positive merit are hard to discern from the written 
record. There is one solitary glimpse but its value as a gauge of what Marshall actually thought may be compromised by its whimsical tone and context. As he told a local Rotary Club in 1923:

I have noticed that scarcely a week passes without my being asked to give a reply to the query: "what good, if any, do mosquitoes do in the world?" I must confess that, up to the present, I have been unable to give any satisfactory answer to this conundrum: but the next time I am asked this question I am going to say: "The mosquito is a two-winged insect to which I am indebted, up to now, for two highly enjoyable visits to Gosport."

(Marshall 1923, BMCI, AMWL)

That does not mean that Marshall adhered to the view, as articulated recently by Janet McAllister of the Centers for Disease Control and Prevention in Fort Collins, Colorado, that "we haven't wanted anything from mosquitoes except for them to go away" (Fang 2010: 433). Nor can we extrapolate that he would be willing to contemplate any available means to rid the world of mosquitoes. And there is no suggestion that he ever wrestled with the profound moral implications of whether it was right to commit specicide, by deliberately wiping out a species. His organization, after all, was not called the British Mosquito Elimination Institute. Despite what he told members of Gosport's Rotary Club, I doubt he would have been happy with total elimination: that would have left nothing for him to study. Journalists wrote of "extermination" as the goal or ideal (Liverpool Courier 1925). But Marshall knew this was unattainable, since unending warfare was required to avoid a return to "the bad old days of 1920" (J.H.P., undated). ${ }^{18}$

In his speech opening the BMCI-in which he name-checked various "white man's graves" (London Evening News 1931) that mosquito control had made safe and habitable, Panama, Havana, Hong Kong, the Malay states and Ismailia-Ross looked ahead to what sounded like a mosquito-tamed utopia: "And the day may come - indeed, I am sure it will come - when all those fertile tracts of the world which are now dominated and ravaged by King Malaria and King Mosquito will be laid open to civilisation" (Marshall 1928: 16; Ross 1926: 486; Times 1925). In fact, his was not an unambiguous call to rid the entire earth. Ross's vision was confined to areas desirable for agricultural development and settlement by white Europeans where malaria was prevalent. Regardless of feasibility, it was simply unnecessary to eradicate mosquitoes wherever they were found. As Ross explained with reference to the control of $A$. aegypti, and "How Panama was made healthy,"

Our work for the general extermination of insect pests is designed chiefly for the protection of cities and towns. We cannot expect-indeed, there is no need-to drive mosquitoes and the like out of jungles and marshy tracts away from civilisation. 
This viewpoint, with its implicit distinction between "country" or "wild" anophelines and peri-domestic varieties such as $A$. aegypti, should not be confused, though, with an enlightened ethos of coexistence through liveand-let-live: whereas native peoples could coexist with mosquitoes in the tropics, the same could not be expected of Europeans. As long as there were uninhabited tracts, or places thinly and sporadically populated by non-Europeans, then there would always be places where the mosquito's empire would remain uncontested.

\section{Restoring agency to a creaturely nuisance}

The "social evil" - to borrow a term popular in 1920s Britain (Country Life 1927: 108) — caused by non-lethal varieties inhabiting the northern frontiers of the mosquito's global imperium has now been effortlessly eclipsed by the far graver evil of its deadly compatriots. And yet the merely annoying mosquito that ruins a camping trip (rather than an English picnic with cucumber sandwiches) provides the springboard for the most recent book on "our deadliest predator." Timothy Winegard's opening gambit is the scenario of an unwitting American vacationer slumping into a lawn chair to relax with a chilled beer after an exerting hike: "Before you can enjoy your first satisfying swig, however, you hear that all-too-familiar sound" (Winegard 2019: 7). Here is Winegard's hook: who would have thought that an insect most of us know as a pesky intrusion on a summer's evening has played such a profound role throughout human history? Reviewers of Winegard's book have highlighted the "tiny" mosquito's "outsize role" and "outsized effects" in our history (Mirsky 2019; Hemingway 2019). The challenge that the irritating, party-pooping mosquito posed to what Hogarth referred to as "the pleasures of outdoor life" in southern England in the early 1920s (Hogarth 1928: 17) is patently trivial compared to the worldwide, centuries-long, life-and-death struggle against its distant deadly relatives. The predicament $A$. detritus created was especially paltry within the wider context of the post-1919 outbreak of malaria epidemics across southern and eastern Europe. In 1923, in the Soviet Union alone, an estimated 18 million people out of 110 million were afflicted by malaria, resulting in over 60,000 deaths (Gachelin and Opinel 2011: 432). Still, the case of one obscure mosquito species along the southern coast of England provides an intriguing example of an insect pest whose role was far from undersized.

\section{Acknowledgements}

The research for this chapter was pursued as a co-investigator on "Taking the bite out of wetlands: Managing mosquitoes and the socio-ecological value of wetlands for wellbeing" ("Wetland Life") (2016-2020), funded by the Valuing Nature Programme (UK) https://valuing-nature.net/about (NERC [Natural Environment Research Council] grant reference number NE/NO13379/1). 


\section{Notes}

1 The headline was prompted by a gathering of medical officers and sanitary inspectors in Surrey (Britain's first) to plan mosquito control in that county for the coming summer. BMCI, AMWL refers to the papers of the British Mosquito Control Institute (BMCI), Hayling Island, Hampshire, in the Sir Ronald Ross Collection, Archives and Manuscripts, Wellcome Library for the History and Understanding of Medicine, London (BMCI, AMWL).

2 Anopheles atroparvus was originally identified as A. maculipennis (Marshall 1938: 2).

3 A. maculipennis/Anopheles atroparvus is zoophilic and lives and hibernates in pigsties, stables and cowsheds.

4 At the time, improved drainage that eliminated bad air and bad waters was offered as the main explanation for ague's demise, but drainage inadvertently created new breeding places in the shape of ditches and canals (Malaria Commission 1927: 28-29).

5 Britain is not mentioned in Evans (1989).

6 MP, LSHTM refers to: John Frederick Marshall Papers, Library and Archives, London School of Hygiene and Tropical Medicine, London (LSHTM).

7 William John Ritchie Simpson was author of studies such as Maintenance of Health in the Tropics (1916) and a founder of the London School of Hygiene and Tropical Medicine.

8 Only in summer are England's temperatures warm enough for an infected mosquito to complete its parasitic cycle (15-20 days). Temperatures and humidity levels are highest along the southern and southeast coasts.

9 This subheading is taken from the title of Chapters 3 and 4 in Hogarth, British Mosquitoes and How to Eliminate Them (1928).

10 For details of Marshall's life and career (he was heir to a family business fortune), see Snow and Snow (2004: 23-28).

11 The Institute, housed in new premises adjacent to Marshall's residence ("Seacourt"), consisted, on the ground floor, of a demonstration museum, laboratory, a drawing and record office, a photographic room, dark room and mechanical workshop, and, on the first floor, a library, projection room, secretarial offices and research areas. After 1925, Hayling Mosquito Control continued to exist as the Hayling Island Branch of BMCI, which remained responsible for local control measures, whereas BMCI concentrated on research (pure and applied), advisory and educational work (BMCI 1928: 3, MP, LSHTM; Marshall 1925a). After 1939, BMCI's work shrank to local mosquito control.

12 James was a retired lieutenant colonel in the Indian Expeditionary Force (IEF) "D," and former IEF assistant director of Medical Services (Sanitary). BMCI's governing council's membership list reads like a roll-call of the great and the good of British imperial and tropical science.

13 Marshall 1925b.

14 Shute's essay ("Mosquito eradication") was reproduced as Appendix A in Hogarth 1928: 125-127.

15 Hayling Mosquito Control, undated, MP, LSHTM.

16 Chemical larvicides, such as disinfectant (cresol) and copper sulphate, were deployed where windy conditions tore apart the surface film of oil or vegetation broke it up, allowing air to reach larvae (Marshall 1921: 1).

17 1920s British mosquito researchers were curious about biocontrol practised elsewhere, such as transplantation of top-water minnow from North Carolina to waters in the northern USA and Central America, and French proposals for stocking young eels (Observer 1922; London Evening News 1926). Recognition of certain aquatic species' larvae consumption did not extend to a larger awareness of the place of mosquito larvae and adults at the bottom of a food pyramid. Researchers have recently revisited the mosquitofish's reputation as a "reliable ally" in mosquito control (Fang 2010: 433).

18 On the pursuit of control and elimination as different goals, see Cockburn 1961. 


\section{Bibliography}

Birmingham Post, 1927. New Force against Mosquitoes. 31 March.

BMCI (British Mosquito Control Institute), 1928. Mosquitoes and Their Control. Exhibit 12, Conversazione, The Royal Society, Burlington House, 17 May. John Frederick Marshall Papers, Library and Archives, London School of Hygiene and Tropical Medicine, London. MP, LSHTM.

BMCI, 1928. Reports presented by the Council and the Director at the Second Annual General Meeting, London, 18 June. BMCI: Hayling Island. MP, LSHTM.

BMCI, 1929-1930. Eighth Report of the Proceedings of the Hayling Island Branch of the British Mosquito Control Institute. 1 January 1929 to 1 January 1930. MP, LSHTM.

BMCI, 1930. Report of the Director, 4th Annual General Meeting. London, 9 December 1930. BCMI: Hayling Island. MP, LSHTM.

British Medical Journal, 1930. Mosquitoes in Britain. 2/3634. 30 August, 328-329.

Buchanan, G.S. and Newsholme, Arthur. 1919. Reports and Papers on Malaria Contracted in England in 1917. In Reports to the Local Government Board on Public Health and Medical Subjects. London: HMSO.

Caprotti, Federico, 2006. Malaria and Technological Networks: Medical Geography in the Pontine Marshes, Italy, in the 1930s. The Geographical Journal 171/2, 145-155.

Chicago Daily Tribune 1914. Mosquito fight begun in Chicago spreading afar. Other states take up campaign against pleasure-killing pest. $16 \mathrm{July,} 13$.

Christophers, S.R. and Bentley, C.A. 1908. Black-water Fever: Scientific Memoirs by Officers of the Medical and Sanitary Departments of the Government in India, New Series, No. 35. Simla: Government of India.

Cockburn, T. Aidan. 1961. Eradication of Infectious Diseases: "control” is an Unending Operation. After "eradication," No Further Effort Is Required. Science, 133/3458, 1050-1058.

Country Life, 1925. Notes. 57/1472. 21 March, 430.

Country Life, 1926. Country Notes. 60/1537. 3 July, 4.

Country Life, 1927. Pardonable Irritation. 66/1592. 23 July, 108.

Daily Express, 1920. New war against Mosquitoes. 28 August.

Daily Mail, 1925. Control of Mosquitoes: Plans to Exterminate Them. 10 August, 15.

Daily Mirror, 1925. Perilous Parasites. 31 August.

Daily News, 1925. Snack from Neck of Scientist: Hayling Island Warfare. 1 September.

Daily Telegraph, 1925. Man Versus Mosquito: Controlling a Pest. 1 September, 12.

Dobson, Mary, 1998. Contours of Death and Disease in Early Modern England. Cambridge: Cambridge University Press.

Dwyer, P.G. Knight, J.M. and Dale, P.E.R., 2016. Planning Development to Reduce Mosquito Hazard in Coastal Peri-Urban Areas: Case Studies in NSW, Australia. In Balanced Urban Development: Options and Strategies for Liveable Cities, eds. B. Maheshwari et al. Basel: Springer International, 555-574.

Evans, Hugh, 1989. European Malaria Policy in the 1920s and 1930s. Isis 80/1, 40-59.

Fang, Janet, 2010. A World Without Mosquitoes. Nature 466, 432-434.

Gachelin, Gabriel and Opinel, Annick. 2011. Malaria Epidemics in Europe after the First World War: The Early Stages of an International Approach to the Control of the Disease. História, Ciências, Saúde-Manguinhos 18/2, 431-469.

Grove, A.J. 1919. Anopheline Mosquitoes in England. V. English Mosquitoes. In Reports to the Local Government Board on Public Health and Medical Subjects, 44-50.

Hall, Marcus. 2010. Environmental imperialism in Sardinia: Pesticides and Politics in the Struggle Against Malaria. In Nature and History in Modern Italy, eds. Marco Armiero and Marcus Hall. Athens: Ohio University Press, 70-86. 
Hayling Mosquito Control. Undated. The Facts about the Salt-Water Mosquito Ochlerotatus Detritus (The Nuisance). Circular No. 7, MP, LSHTM.

Hemingway, Janet. 2019. A New Tome Traces the Outsized Effects the Mosquito Has Had on Human History. Science, 30 July, https://blogs.sciencemag.org/books/2019/ 07/30/the-mosquito/

Hogarth, A. Moore. 1928. British Mosquitoes and How to Eliminate Them. London: Hutchinson.

J.H.P., undated. Where the Mosquito Meets His Fate: Avengers at Hayling Island; a War That Never Ends. MP, LSHTM.

James, S.P. 1920. Malaria at Home and Abroad. London: John Bale.

James, S.P. 1929. The Disappearance of Malaria from England. Proceedings of the Royal Society of Medicine 23, 71-87.

Knight, J., Dale, P. Dwyer, P. and Marx, S. 2017. A Conceptual Approach to Integrate Management of Ecosystem Service and Disservice in Coastal Wetlands. AIMS Environmental Science 4/3, 431-440.

Liverpool Courier, 1925. Mosquito Peril to Man. Institute to Wage War of Extermination. 1 September.

Liverpool Evening Express, 1928. The Mosquito. 17 January.

London Evening News, 1926. Sticklebacks to Rescue. 9 August.

London Evening News, 1931. Those Mosquitoes. 13 August.

London Evening Standard, 1925. War on England's Mosquitoes: How Hayling's Summer Swarms Were Removed. 31 August.

MacArthur, W.P. 1951. A Brief History of English Malaria. British Medical Bulletin 8, 76-79.

Macdonald, Angus. 1919. Report on Indigenous Malaria and on Malaria Work Performed in Connection with the Troops in England during the Year 1918. In Observations on Malaria by Medical Officers of the Army and Others, ed. Ronald Ross. London: War Office/HMSO, 178-258.

Macdonald, George. 1965. Eradication of Malaria. Public Health Reports 80/10, 870-879.

Macfarlane, R. 2012. Item of the Month, April 2012: On Indigenous Malaria. 25 April, http://blog.wellcomelibrary.org/2012/04/item-of-the-month-april-2012-on-ind igenous-malaria/

Malaria Commission. 1927. Principles and Methods of Antimalarial Measures in Europe. In Second General Report of the Malaria Commission, doc. C.H./Malaria/73. Geneva: League of Nations Health Organisation.

Manchester Guardian, 1925. English Mosquito Scare. 11 June, 18.

Manchester Guardian, 1929. The Mosquito in our Midst. 29 August, 8.

Marshall, J.F. 1921. The Destruction of Mosquito Larvae in Salt or Brackish Water. Hayling Mosquito Control, Circular No. 6, Marshall, LSHTM.

Marshall, J.F. 1923. Lecture to Gosport Rotary Club, 19 July, British Mosquito Control Institute [Unit] (BMCI), Hayling Island, Hampshire, Sir Ronald Ross Collection, Archives and Manuscripts, Wellcome Library for the History and Understanding of Medicine. BMCI, AMWL.

Marshall, J.F. 1924. A Report on the Anti-Mosquito Operations Carried out by the Hayling Mosquito Control during the Period October,1922 to February,1924 Inclusive (15 March). Marshall, LSHTM.

Marshall, J.F. 1925a. Fighting the English Mosquito: The Hayling Island Institute. Illustrated London News, 12 September, 475.

Marshall, J.F. 1925b. Coastal Mosquitoes and Their Control. A Paper Read before the Zoology Section of the British Association for the Advancement of Science [Southampton Meeting], 27 August, Marshall, LSHTM. 
Marshall, J.F. 1927. Account of the Origin of the British Mosquito Control Institute (presented to the Council of the Institute. 30 March 1927, BMCI, AMWL.

Marshall, J.F. 1928. Principles and Practice of Mosquito Control: Being a Handbook to the British Mosquito Control Institute. Hampshire: Hayling Island.

Marshall, J.F. 1930. The Organization of Mosquito Control Work. Presidential Address, Zoology Section, South Eastern Union of Scientific Societies, Portsmouth Congress, May. Marshall, LSHTM.

Marshall, J.F. 1933. Mosquito Control in Dorset (letter to the editor). Portsmouth Evening News, 11 September 1933. Marshall, LSHTM.

Marshall, J.F. 1938. A Revised List of the British Mosquitoes, with Some Notes Regarding Those Discovered in England since the Year 1918 (No. 30), 2.

Marshall, J.F. 1942. Mosquito-Breeding in Static Water Supplies. Nature 149, 2.

Marshall, J.F. Undated a. The Organization and Operation of a Mosquito Control. Marshall, LSHTM.

Marshall, J.F. Undated b. A Mosquito Summary. BMCI: Hayling Island, AMWL.

Ministry of Health, 1949. Memorandum on Measures for the Control of Mosquito Nuisances in Great Britain. London: HMSO.

Ministry of Health, 1962. Memorandum on Measures for the Control of Mosquito Nuisances in Great Britain. London: HMSO.

Mirsky, Steve. 2019. The Outsize Role of Tiny Mosquitoes in Human History. Scientific American, October, https://www.scientificamerican.com/article/the-outsize-role-of -tiny-mosquitoes-in-human-history/

Morning Post, 1925a. Hayling Island Mosquito Control: New Stage in the Work. 16 March.

Morning Post, 1925b. Routing the Mosquito: The Hayling Island war; World's Interest in British Methods. 31 August.

Nature, 1949. Mr. J.F. Marshall, C.B.E. (obituary), 165. 7 January, 16.

Newman, George. 1919. Reports and Papers on Malaria Contracted in England in 1918 (June 1919). In Reports to the Local Government Board on Public Health and Medical Subjects. London: HMSO, New Series, No. 123, 1-42.

Newsholme, Arthur. 1918. Reports and Papers on Malaria Contracted in England in 1917 (June 1918. In Reports to the Local Government Board on Public Health and Medical Subjects. London: HMSO, New Series, No. 119, Appendix 2.

Observer, 1922. The Fish Cure for Mosquitoes: Successful Experiments in America. 12 November, 9.

Observer, 1925. The Campaign against Insect Pests: Interview with Sir Ronald Ross. 30 August, 5.

O'Gorman, Emily. 2017. Imagined Ecologies: A More-Than-Human History of Malaria in the Murrumbidgee Irrigation Area, New South Wales, Australia, 1919-1945. Environmental History 22, 486-514.

Olver, Chris. 2014. Malaria in the UK (25 April). Library and Archives Service Blog, LSHTM, https://blogs.lshtm.ac.uk/library/2014/04/25/malaria-in-the-uk/

Parsons, A.C. 1919. Practical Notes on Mosquito Surveys of Camps and Barracks during 1917 and 1918. In Observations on Malaria by Medical Officers of the Army and Others, 95-112.

Patterson, Gordon. 2009. The Mosquito Crusades: A History of the American Anti-Mosquito Movement from the Reed Commission to the First Earth Day. New Brunswick, NJ: Rutgers University Press.

Patterson, Gordon. 2016. Looking Backward, Looking Forward: The Long, Torturous Struggle with Mosquitoes. Insects 7, 1-14, https://doi.org/10.3390/insects7040056 
Peacock, T.B. 1859. On Recently Prevalent Malarious Affections. Medical Times and Gazette 19, 399-400, 453-455, 478-479.

Portsmouth Gazette, 1930. Today. 5 March.

Ross, Ronald. 1902. Mosquito Brigades and How to Organize Them. London: George Philip.

Ross, Ronald. 1919, An Interim Report on the Treatment of Malaria - Abstract of 2,460 Cases. In Observations on Malaria by Medical Officers of the Army and Others, 323-327.

Ross, Ronald. 1926. The Importance of Mosquito Control. Science Progress in the Twentieth Century (1919-1933) 20/79, 481-486.

Service, Mike W. 2003. Ross Letters, Press Cuttings, Hayling Island Institute. 22 October, BMCI, AMWL.

Shaw, Ian Graham Ronald, Robbins, Paul F. and Jones, John Paul III. 2010. A bug's Life and the Spatial Ontologies of Mosquito Management. Annals of the Association of American Geographers 100/02, 375.

Smith, John. 1904. Report of the New Jersey Agricultural Experiment Station upon Mosquitoes Occurring within the State, Their Habits, Life History, Etc. Trenton: New Jersey Agricultural Experiment Station.

Snow, Keith R. 1998. Distribution of Anopheles Mosquitoes in the British Isles. European Mosquito Bulletin 1, 9-13.

Snow, Keith R. and Snow, Susan E. 2004. John Frederick Marshall and "The British Mosquitoes." European Mosquito Bulletin: Journal of the European Mosquito Control Association 17, 23-28.

Soper, Fred L. 1965. Rehabilitation of the Eradication Concept in the Prevention of Communicable Diseases. Public Health Reports 80/10, 855-869.

Stepan, Nancy Leys. 2011. Eradication: Riding the World of Diseases Forever? London: Reaktion.

Sutter, Paul S. 2007. Nature's Agents or agents of Empire?: Entomological Workers and Environmental Change during the Construction of the Panama Canal. Isis 98/4, 724-754.

The Children's Newspaper, 1928. Hayling Island's War: Conquering the Mosquito. 29 September, Marshall, LSHTM.

The Field, 1924. Hayling Island Mosquitoes. 25 September, 502-503.

The Lancet, 1925. British Mosquito Control Institute. 5 September.

The Times, 1925. British Mosquito Conquered: Work at Hayling Island; new Institute Opened. 1 September, 14.

The Times, 1926. Mosquitoes in Epping Forest: A Summer Nuisance. 13 August.

Turnbull, R.E. 1925. Controlling the Mosquito in Britain: Campaign Methods. Illustrated London News, 4 August, 228.

West Africa, 1927. Mosquito Pest Conference - in England! 12 March.

Western Mail, 1925. Mosquito or man? Case of Survival of the Fittest. 1 September.

Westminster Gazette, 1927. New War on the Mosquito: Legislation Need Emphasised. 31 March.

Winegard, Timothy. 2019. The Mosquito: A Human History of our Deadliest Predator. New York: Penguin.

Yorkshire Post, 1927. British Mosquito Pest: Health Ministry official Suggests Legislation. 31 March. 


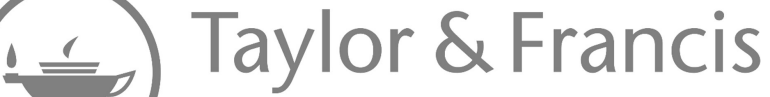

Taylor \& Francis Group

http://taylorandfrancis.com 